\title{
Habitat-mediated survivorship of juvenile (0-year) Atlantic cod Gadus morhua
}

\author{
James B. Lindholm ${ }^{1, *}$, Peter J. Auster ${ }^{1}$, Les S. Kaufman ${ }^{2}$ \\ ${ }^{1}$ National Undersea Research Center for the North Atlantic \& Great Lakes, University of Connecticut at Avery Point, \\ Groton, Connecticut 06340, USA \\ ${ }^{2}$ Boston University Marine Program, Boston University, Marine Biological Laboratory, Woods Hole, \\ Massachusetts 02543, USA
}

\begin{abstract}
Fishing activity can impact fish populations in 2 ways. The first is the immediate effect on population demographics by the removal of fish. Second is the impact of fishing (e.g. bottom trawls and dredges) on the seafloor which can reduce habitat structure and thus increase the vulnerability of juvenile fish to predation by older conspecifics and other predators. We conducted laboratory experiments to investigate the role of variability in seafloor habitat structure on the survivorship of post-settlement juvenile (0-yr) Atlantic cod Gadus morhua. Groups of 0 -yr cod were exposed to a foraging predator $(3+\operatorname{cod})$ over 5 seafloor habitats of varying complexity (sand, cobble, minimum density short sponge, maximum density short sponge, and tall sponge). These habitats were selected to mimic the range of impacts of mobile fishing gear given a gradient in fishing effort. Emergent epifauna resulted in a significant decrease in 0-yr mortality when compared to flat sand, the least complex habitat. Epifaunal density was shown to be more significant than epifaunal height in reducing 0-yr mortality. Predator reaction distance decreased with increasing habitat complexity, presumably due to the obstruction of visual cues by complex relief. Latency to first and second capture did not differ statistically between habitats. Alteration of seafloor habitat by fishing activity in the northwest Atlantic could magnify the effects of overfishing by limiting juvenile survivorship.
\end{abstract}

KEY WORDS: Seafloor habitat $\cdot 0$-year cod $\cdot$ Mortality $\cdot$ Survivorship Predation

\section{INTRODUCTION}

A great deal of scientific research has focused on large-scale planktonic egg and larval mortality as a factor contributing to annual fluctuations in year-class strength of fishes in temperate and boreal systems (Anderson 1988). Less attention has been given to small-scale, localized processes affecting population dynamics (see Auster 1988) even though mortality during this life history stage is sufficient to significantly modify population size (Sissenwine 1984, Sogard 1997).

The physical substratum of the seafloor, combined with biogenic structures that rise above it, serves as

\footnotetext{
- Present address: National Undersea Research Center for the North Atlantic \& Great Lakes, University of Connecticut at Avery Point, 1084 Shennecossett Road, Groton, Connecticut 06340, USA. E-mail: lindholm@uconnvm.uconn.edu
}

cover for many species of demersal fishes. Associations between fishes and seafloor habitats are well documented in tropical reef systems (e.g. Sale 1991), temperate seagrass beds (e.g. Heck \& Crowder 1991), and shallow rock reef systems (e.g. Carr 1991, Connell \& Jones 1991). However, the role of habitat-mediated post-settlement survivorship has only recently been addressed for outer continental shelf species like Atlantic cod Gadus morhua, despite their great economic importance. Laboratory experiments have demonstrated a preference of 0 -yr cod for cobblegravel substratum over gravel or sand in the presence of both foraging and non-foraging predators, with increased survivorship over cobble-gravel (Gotceitas \& Brown 1993, Gotceitas et al. 1995, Fraser et al. 1996). Here the cod used the interstices between gravel as refugia from predation. Similar results have been obtained in eelgrass patches (Gotceitas et al. 1997). Field work using submersibles has identified associa- 
tions between fishes and particular microhabitat features (Lough et al. 1989, Auster et al. 1991, 1995, Gregory et al. 1997). Field studies in the nearshore environment of Nova Scotia (Tupper \& Boutilier 1995a,b) indicate that survivorship and growth rate of juvenile cod increased with habitat complexity (e.g. bare sand to cobble, eelgrass and rock reef), while predator efficiency decreased. These and other studies that show juvenile fish associations with specific microhabitat resources provide evidence of an explicit connection between the survival of juvenile fish and the complexity of seafloor habitat (Auster \& Malatesta 1991, Auster et al. 1995, Tupper \& Boutilier 1995a). At the population level this implies that, for some species, recruitment dynamics may be mediated by the integrity of seafloor habitats.

With the realization that fishing pressure around the world is exceeding sustainable limits, there is mounting pressure for the reduction of fishing mortality using traditional effort controls, e.g. limitations on vessel days at sea, net and mesh size restrictions, and catch quotas. These controls focus on the reduction of excess removal of fish through overfishing and the corresponding increase in spawning stock biomass that results. However a second and potentially equally important environmental impact occurs simultaneously, as fishing gear used to catch species of demersal fish and shellfish (e.g. otter and roller-rigged beam trawls, and scallop dredges) is dragged across the seafloor (Langton 1994, Auster et al. 1996, Schwinghamer et al, 1996, Auster \& Langton 1999, Freese et al. 1999). This is a major physical disturbance that eliminates significant amounts of the vertical relief provided by different substrata and their associated epibionts which is not dealt with explicitly by traditional effort controls. Auster et al. (1996) showed that mobile fishing gear reduced seafloor habitat complexity through the removal of both biogenic (e.g. sponges, hydrozoans, and amphipod tubes) and sedimentary (e.g. sandwaves and depressions) structures, as well as organisms that create structure (e.g. crabs and scallops) at 3 sites in the Gulf of Maine. Further, Auster et al. (1996) use fishing effort data to show that the Gulf of Maine is, if averaged across the entire region, impacted more than once annually and Georges Bank is impacted 2 to 4 times annually. In actuality, the spatial extent of fishing effort is heterogeneous, indicating that certain areas are not impacted at all, while other areas are impacted far more than 2 to 4 times annually. This suggests that traditional control efforts which do not explicitly address seafloor habitat alteration may reduce the number of times a particular patch of the seafloor is dragged, but will not necessarily result in a reduction in the total area of bottom that is dragged.
In a study of the effects of scallop dredging on seafloor habitat on the northeast peak of Georges Bank, Collie et al. (1997) found that the numerical abundance of the emergent tube-dwelling polychaete Filograna implexa was significantly higher at undredged sites than at dredged sites. Similar results were found in the Gulf of Alaska (Freese et al. 1999), with a significant decrease in density of sponges and anthozoans, as well as an increase in damage to such organisms, in trawled areas relative to untrawled reference sites. Fishing activity can also alter food web dynamics by disrupting benthic organisms that are prey for many harvested fish species. Kaiser \& Spencer (1994) found increased intake of prey (e.g. amphipods and scallops) for several fish species which foraged in an area recently disturbed by a $4 \mathrm{~m}$ beam trawl.

Following settlement, juvenile gadids are subject to a suite of potential predators (e.g. sea raven Hemitripterus americanus, longhorn sculpin Myoxocephalus octodecimspinosus, grubby Myoxocephalus aeneus, spiny dogfish Squalus acanthias, silver hake Merluccius bilinearis, and larger conspecifics; see Scott \& Scott 1988, Tupper \& Boutilier 1995a). The identification of demographically important seafloor habitat features and the ways in which they mediate predator-induced mortality of juvenile fishes requires a combination of field, laboratory and modeling studies that link smallscale processes to regional-scale population variation. Here we describe laboratory experiments where 0 -yr cod were exposed to predation by a foraging predator $(3+\operatorname{cod})$ in a laboratory aquarium. Mimics of 5 seafloor habitats were designed to represent biogenic habitats found on the offshore banks of the northwest Atlantic. Habitat heights and densities for each experiment were selected to mimic a gradient of impacts produced by mobile fishing gear in order to examine the role of fishing activity in 0 -yr cod survivorship.

\section{METHODS}

Predation experiments were conducted in a glass, temperature-controlled, flow-through aquarium measuring $1.83 \times 0.63 \times 0.66 \mathrm{~m}$ deep (Fig. 1). Water temperature in the aquarium was maintained at 8 to $10^{\circ} \mathrm{C}$ throughout the experiments. A $12 \mathrm{~h}$ light-dark regime was maintained by four $110 \mathrm{~W}$ fluorescent lights suspended $2.5 \mathrm{~m}$ above the aquarium. Three of the 4 sides of the aquarium were opaque and all observations were conducted from behind a blind to eliminate disturbance by the observer. A predator enclosure measuring $0.58 \times 0.63 \times 0.66 \mathrm{~m}$ deep was partitioned on the left side of the aquarium. A sliding door measuring 30 $\times 50 \mathrm{~cm}$ was opened from behind the blind to admit predators into the experimental arena. 


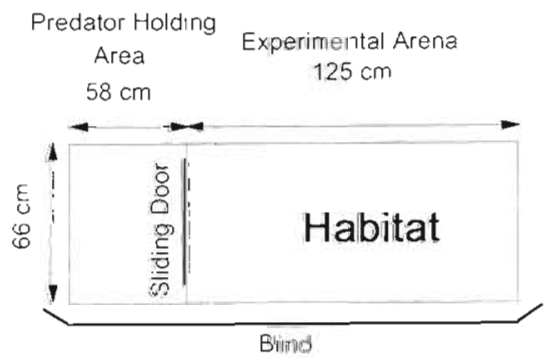

Fig. 1. Schematic depicting experimental aquarium

Habitat treatments were selected based on field observations of seafloor habitats found in the Gulf of Maine and on Georges Bank (Lough et al. 1989, Langton et al. 1995, Auster 1998). The treatments were: sand, cobble, minimum density short sponge (SS min), maximum density short sponge (SS max), and tall sponge (Tall sp). Sand and cobble were collected along the shoreline and were washed and dried in the sun prior to the experiments (sand $<1 \mathrm{~mm}$ diameter; cobble 60 to $80 \mathrm{~mm}$ diameter). In order to insure uniformity of habitat structure within and between treatments, epifaunal mimics were created using synthetic sponge. Sponges were $2.5 \times 4 \mathrm{~cm}$ and were either $15 \mathrm{~cm}$ (Tall sp) or $8 \mathrm{~cm}$ (SS min and SS max) high. Sponges were attached to cobble using $100 \%$ clear silicone rubber. Sand habitat consisted of flat sand with no depressions or ripples other than those created by the cod during an experimental trial. Cobble habitat consisted of cobbles resting on sand (with small crevices or interstices present) at a separation distance of $8 \mathrm{~cm}$. Epifaunal density effects were tested using short sponges at maximum (SS max) and minimum (SS min) densities (i.e. 8 and $15 \mathrm{~cm}$ separation). Epifaunal height effects were tested with Tall sp at a $15 \mathrm{~cm}$ horizontal separation distance (a density effects treatment was not possible due to limited availability of 0 -yr cod). All 5 habitats covered the entire bottom of the experimental arena.

We obtained cultured $0-y \mathrm{r}$ cod $(7$ to $10 \mathrm{~cm}$ total length, TL) from the Aquaculture Project at the University of Maine at Orono and housed in a separate flow-through aquarium. The cod were acclimated to local water conditions for $3 \mathrm{wk}$ prior to experimentation. We collected predators on Coxe's Ledge, south of Point Judith, Rhode Island. Individual $3+$ cod were captured using hook and line. These fish were also held separately and acciimated to local water conditions for 3 wk prior to experimentation.

Two $3+$ cod were trained to enter the experimental arena to feed for $2 \mathrm{wk}$ prior to experiments. Live 0 -yr cod and mummichogs Fundulus heteroclitus were fed to predators prior to experimentation to develop a visual search image. Most teleost fish are primarily sight-oriented predators, relying on olfaction and chemosensory abilities in adverse water conditions (Bond 1996). Observations of the 2 predators prior to experimentation indicated that, within the experimental arena, food was located by sight. Predators were fed every third day up to the beginning of the experiment. Prey mortality in these training trials did not exceed 3 prey consumed predator ${ }^{-1}$ trial $^{-1}$. During the experiments predators were fed only during experimental trials, with each predator used every third day for experimentation

A total of 25 experiments were conducted, consisting of 5 replicates for each of the 5 habitat treatments. Each experimental trial lasted $1.5 \mathrm{~d}$ and consisted of predator and prey exposure to a single habitat type. At 17:00 h on Day 1 of the experiment, a group of experimentally naive 0 -yr $\operatorname{cod}\left(n=3\right.$ fish group ${ }^{-1}$, mean $=$ $8.37 \mathrm{~cm} \mathrm{TL}, \mathrm{SE}=1.13 \mathrm{~cm}$ ) were introduced to the experimental arena and a single predator $(3+\operatorname{cod}, 38$ to $40 \mathrm{~cm} \mathrm{TL}$ ) was introduced to the predator enclosure for acclimation to the experimental aquarium. Position of 0 -yr individuals, relative to each habitat type, was observed for 5 min prior to introduction of the predator. At 10:00 h on Day 2 the predator was released into the experimental arena. Each experimental trial lasted $4 \mathrm{~h}$, ending at 14:00 h on Day 2. Predators were alternated for each replicate, with each predator being used in an experiment every third day (consistent with feeding schedule prior to experimentation). Observation of each experimental trial was continuous throughout the $4 \mathrm{~h}$ period.

Quantitative observations during experiments included total 0-yr mortality, latency to first and second capture, predator reaction distance for first and second capture. Latency to prey capture and predator reaction distance were measured to identify how habitat-mediated processes affect 0 -yr cod mortality. Data were recorded on an event recorder and later transcribed for analysis. Total 0 -yr mortality was calculated as the total number of prey consumed during each trial. Latency to first capture was calculated as the time elapsed from predator introduction into the experimental arena to the first prey capture. Latency to second capture represents the time elapsed between first and second capture. Predator reaction distance (measured against a calibrated background) was the observed distance between predator and prey at the initial point of encounters which ended in either a strike or a capture. Order of exposure to habitats was selected randomly to reduce predator learning effects.

Statistical assumptions which underlie parametric analyses were tested using the Ryan-Joiner test of normality (Minitab 1994). Data were transformed (e.g. arcsin, $\log _{10}$, square root) where appropriate. A 2-way ANOVA (Generalized Linear Model Procedure) was conducted to identify any predator-habitat interaction 
for each metric (Sokal \& Rohlf 1995). Replicates using individual predators were pooled for analysis because no predator-habitat interaction occurred and because individual predator responses with respect to each of the 5 metrics were similar. Post hoc analyses on the pooled data were conducted using a Bonferroni/Dunn test for multiple comparisons to identify significant differences between habitat types for each metric (Kleinbaum et al. 1988).

\section{RESULTS}

Results of the 2-way ANOVA are provided in Table 1. Relative differences in total, habitat-specific 0 -yr mortality for each of the 5 habitat types are presented in Fig. 2. Analysis of total mortality revealed a highly significant difference between habitats (2-way ANOVA, $F=8.86, p<0.001$ ). Post hoc analysis of differences between habitats using the Bonferroni/Dunn test for multiple comparisons revealed significant differences between habitat types (Table 2). The presence of any emergent structure projecting above the

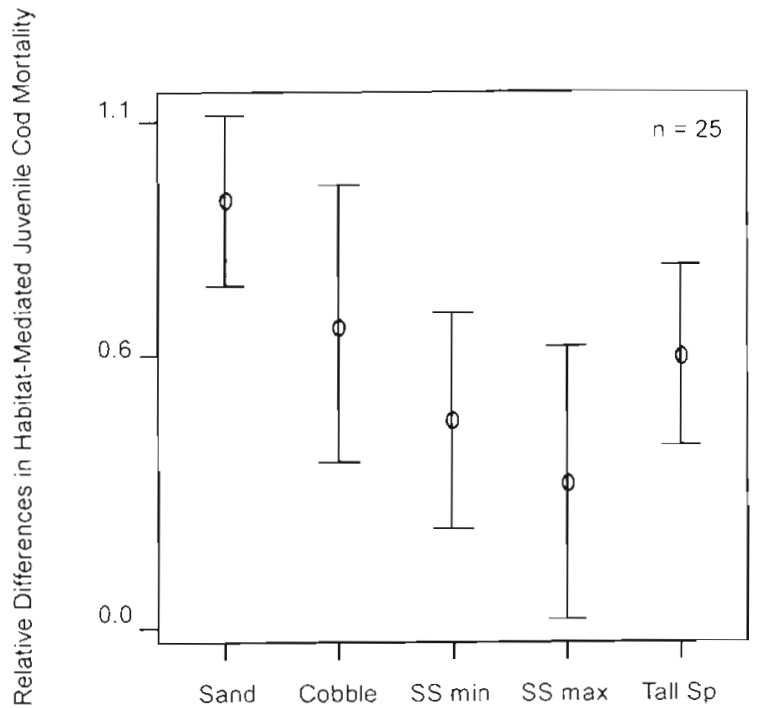

Fig. 2. Comparison of relative differences in juvenile cod mortality between habitat types (arcsine transormed). Means are reported with $95 \%$ confidence interval. SS min, SS max: minimum and maximum density short sponge; Tall sp: tall sponge

Table 1. Results of 2-way ANOVA (Generalized Linear Model) used to test for effects of habitat, predator and predator-habitat interaction on 0 -yr cod mortality

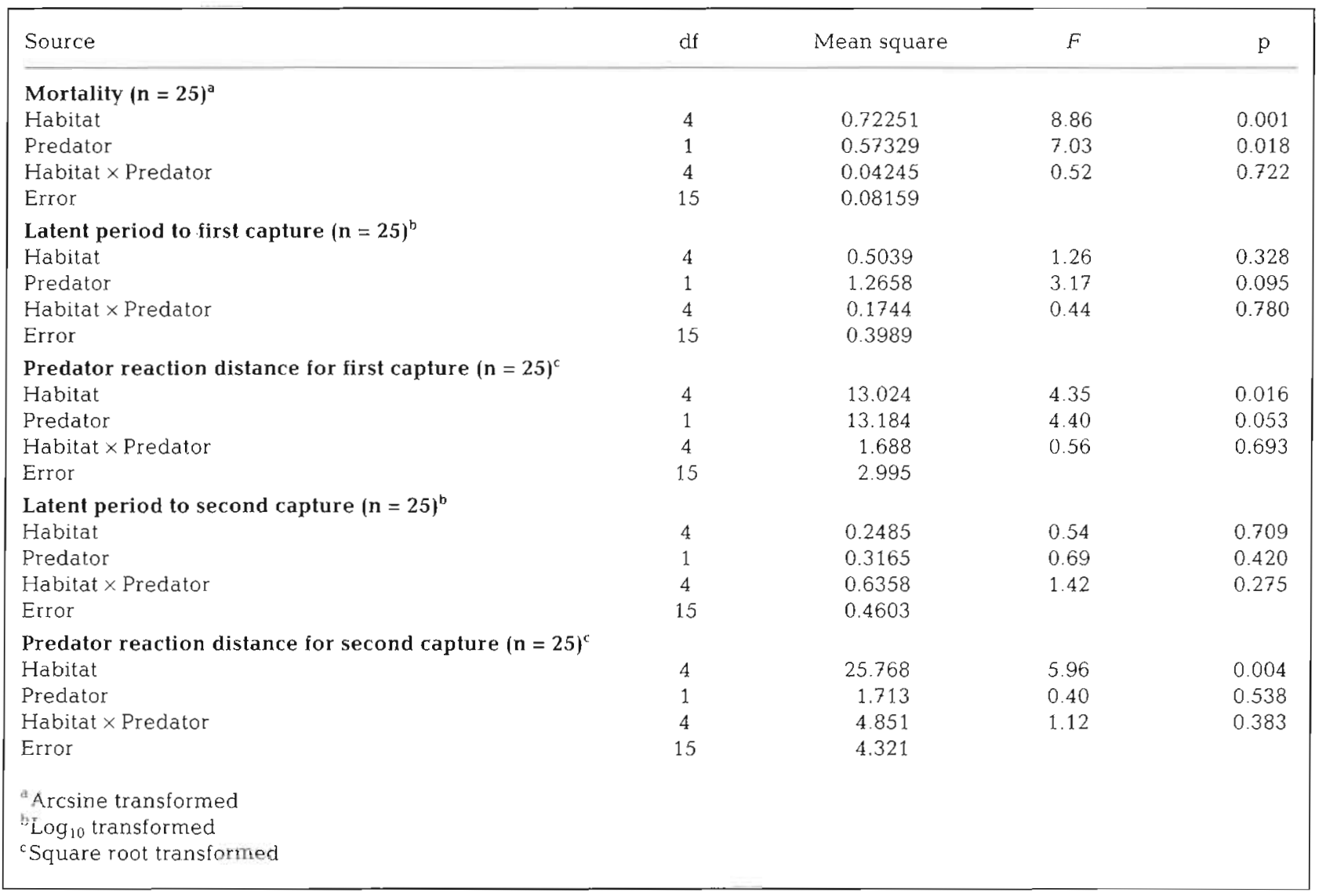


Table 2. Results of Bonferonni/Dunn tests for multiple comparisons between habitat types. Total juvenile cod mortality, latent period to first and second juvenile cod capture, and predator reaction distance for first and second capture are compared by habitat type. Mean difference and p-value are reported. SS min, SS max: minimum and maximum density short sponge; Tall sp: tall sponge

\begin{tabular}{|c|c|c|c|c|c|c|c|c|c|c|}
\hline \multirow[t]{2}{*}{ Habitats } & \multicolumn{2}{|c|}{$\begin{array}{c}\text { Total } \\
\text { mortality } \\
(\% 0-y r \\
\text { captured })\end{array}$} & \multicolumn{2}{|c|}{$\begin{array}{l}\text { Latent period } \\
\text { to first } \\
\text { capture } \\
\text { (min) }\end{array}$} & \multicolumn{2}{|c|}{$\begin{array}{c}\text { Predator } \\
\text { reaction distance } \\
\text { for first } \\
\text { capture }(\mathrm{cm})\end{array}$} & \multicolumn{2}{|c|}{$\begin{array}{l}\text { Latent period } \\
\text { to second } \\
\text { capture } \\
\text { (min) }\end{array}$} & \multicolumn{2}{|c|}{$\begin{array}{c}\text { Predator } \\
\text { reaction distance } \\
\text { for second } \\
\text { capture }(\mathrm{cm})\end{array}$} \\
\hline & $\begin{array}{l}\text { Mean } \\
\text { diff. }\end{array}$ & $\mathrm{p}$-value & $\begin{array}{c}\text { Mean } \\
\text { diff. }\end{array}$ & p-value & $\begin{array}{c}\text { Mean } \\
\text { diff. }\end{array}$ & $p$-value & $\begin{array}{c}\text { Mean } \\
\text { diff. }\end{array}$ & p-value & $\begin{array}{l}\text { Mean } \\
\text { diff. }\end{array}$ & $p$-value \\
\hline $\begin{array}{l}\text { Sand vs } \\
\text { Cobble }\end{array}$ & 0.582 & $0.0082^{\mathrm{b}}$ & -0.345 & 0.3969 & 0.192 & 0.3819 & 0.339 & 0.4535 & 36.00 & $0.0007^{a}$ \\
\hline $\begin{array}{l}\text { Sand vs } \\
\text { SS min }\end{array}$ & 0.908 & $0.0002^{\mathrm{d}}$ & -0.532 & 0.1974 & 0.470 & $0.0408^{b}$ & 0.335 & 0.4590 & 42.00 & $0.0001^{d}$ \\
\hline $\begin{array}{l}\text { Sand vs } \\
\text { SS max }\end{array}$ & 1.055 & $0.0001^{\mathrm{d}}$ & 0.136 & 0.7361 & 0.845 & $0.0008^{\mathrm{d}}$ & 0.730 & 0.1156 & 47.00 & $0.0001^{\mathrm{d}}$ \\
\hline $\begin{array}{l}\text { Sand vs } \\
\text { Tall sp }\end{array}$ & 0.749 & $0.0012^{a}$ & -0.073 & 0.8567 & 0.266 & 0.2306 & 0.239 & 0.5962 & 31.00 & $0.0024^{a}$ \\
\hline $\begin{array}{l}\text { Cobble vs } \\
\text { SS min }\end{array}$ & 0.326 & 0.1154 & -0.186 & 0.6452 & 0.278 & 0.2109 & -0.004 & 0.9925 & 6.00 & 0.5100 \\
\hline $\begin{array}{l}\text { Cobble vs } \\
\text { SS max }\end{array}$ & 0.473 & $0.0270^{\mathrm{b}}$ & 0.481 & 0.2413 & 0.653 & $0.0065^{\mathrm{b}}$ & 0.391 & 0.3891 & 11.00 & 0.2330 \\
\hline $\begin{array}{l}\text { Cobble vs } \\
\text { Tall sp }\end{array}$ & 0.167 & 0.4089 & 0.272 & 0.5025 & 0.375 & 0.0964 & -0.10 & 0.8234 & -5.00 & 0.5824 \\
\hline $\begin{array}{l}\text { SS min vs } \\
\text { SS max }\end{array}$ & 0.147 & 0.4677 & 0.668 & 0.1095 & -0.204 & 0.3534 & 0.395 & 0.3841 & 5.00 & 0.5824 \\
\hline $\begin{array}{l}\text { SS min vs } \\
\text { Tall sp }\end{array}$ & -0.159 & 0.4317 & 0.459 & 0.2635 & -0.579 & 0.0139 & -0.096 & 0.8307 & -11.00 & 0.2330 \\
\hline $\begin{array}{l}\text { SS max vs } \\
\text { Tall sp }\end{array}$ & -0.206 & $0.0886^{c}$ & -0.209 & 0.6056 & -26.00 & $0.0827^{c}$ & -0.491 & 0.2816 & -16.00 & $0.0888^{c}$ \\
\hline $\begin{array}{l}{ }^{a} \text { Difference } \\
{ }^{\circ} \text { Difference } \\
{ }^{c} \text { Difference }\end{array}$ & $\begin{array}{l}\text { s signific } \\
\text { s signific } \\
\text { s signific }\end{array}$ & $\begin{array}{l}\text { nt for } \alpha= \\
\text { nt for } \alpha= \\
\text { nt for } \alpha=\end{array}$ & & & & & & & & \\
\hline
\end{tabular}

sand bottom produced a significant reduction in total mortality over bare sand habitat. Furthermore, mortality was lower in the 2 short sponge treatments than over bare cobble, with a drop in total mortality of $50 \%$ from cobble to SS max. Density of emergent epifauna (total mortality for SS max averaged $32.2 \%$ ) proved to be more important than height (total mortality for Tall sp averaged $60.2 \%$ ) for 0 -yr survivorship.

Prior to the introduction of the predator, $0-y r \operatorname{cod}$ were dispersed throughout the experimental arena (i.e. swimming at the air-water interface, through the water column, and around any structure provided) and were observed to both aggregate as a group and to individually disperse. Following introduction of the foraging predator, 0 -yr cod would quickly seek to distance themselves from the predator, although not always using the cover provided by the structure on the bottom. After a strike or capture, 0-yr cod were observed to exhibit a wide range of behaviors. In the absence of high-relief structure on the bottom, 0 -yr cod often moved quickly to the air-water interface, plac- ing the maximum possible distance between themselves and the predator. Where structure was provided, either cobble bottom or cobble with sponge mimics, 0-yr cod often sought cover in the habitat. Individual 0 -yr cod were observed swimming down within the emergent habitat structure, while others would seek immediate refuge at the base of a cobble and remain immobile, in some cases for the duration of the trial.

Predators were trained to feed immediately following introduction to the experimental arena. However, the latent period to first 0 -yr capture (Fig. 3) did not vary as expected with habitat type. Analysis of latency to first capture showed no significant difference between habitat types (2-way ANOVA, $F=1.26$, p < 0.328 ). Analysis of predator reaction distance for first capture (Fig. 4) indicated a significant difference between habitat types (2-way ANOVA, $F=4.15, p<$ 0.018 ). Results of the Bonferroni/Dunn test showed significant differences between predator reaction distance for sand and both SS min and SS max (Table 2). 


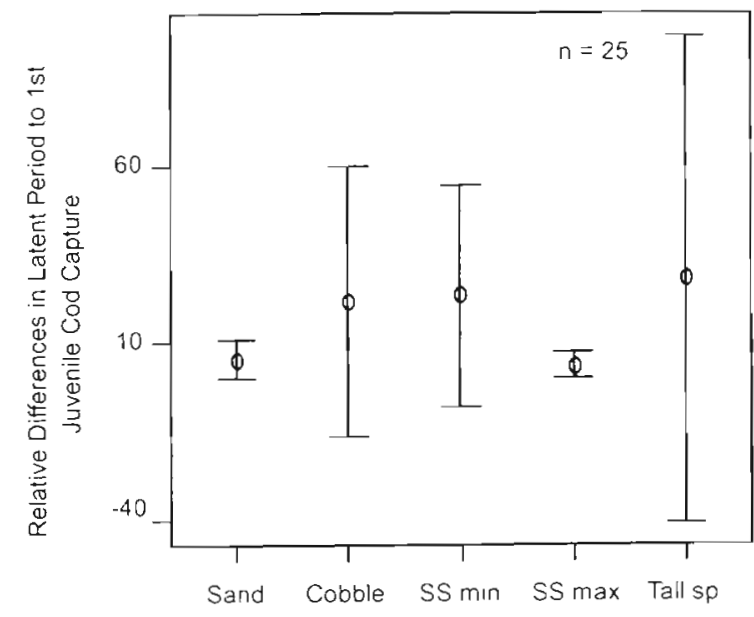

Fig. 3. Comparison of relative differences in latent period to first juvenile cod capture between habitat types ( $\log _{i n}$ transformed). Means are reported with $95 \%$ confidence interval

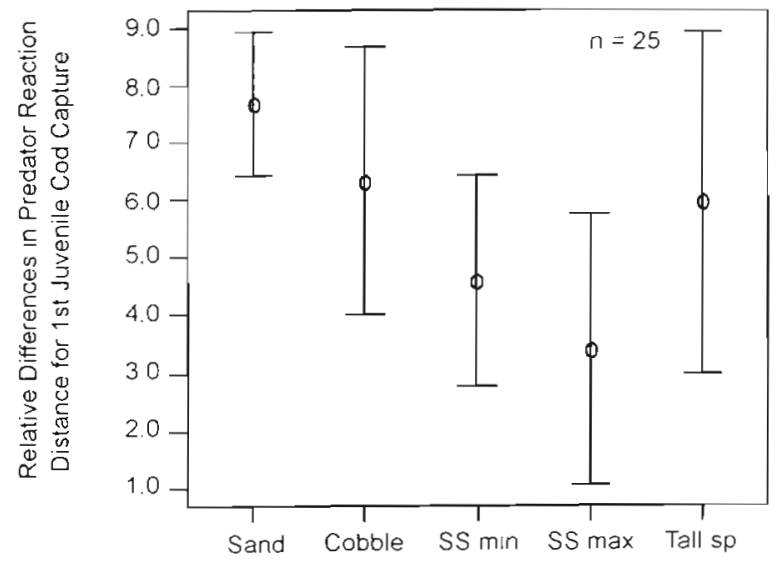

Fig. 4. Comparison of relative differences in predator reaction distance for first juvenile cod capture between habitat types (square root transformed). Means are reported with $95 \%$ confidence interval

For encounters over bare sand habitat which ended in prey capture, predators were observed to react to a prey from an average distance of $60 \mathrm{~cm}(\mathrm{SD}=15.81)$. For similar encounters over SS min and SS max, predator reaction distances were observed to average $23 \mathrm{~cm}$ $(\mathrm{SD}=15.65)$ and $14 \mathrm{~cm}(\mathrm{SD}=14.94)$, respectively. As cod can identify prey using visual cues, the reduction in predator reaction distance with increasing habitat complexity was expected. With 0 -yr fish swimming down in emergent habitat, predators often did not encounter prey until passing directly above them, as opposed to encounters over sand in which the prey were located from a significant horizontal distance across the experimental arena.

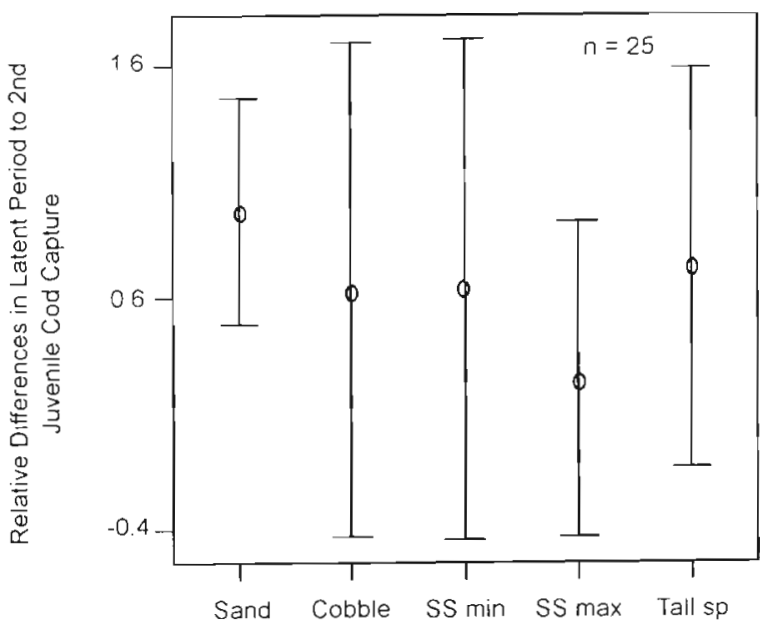

Fig. 5. Comparison of relative differences in latent period to second juvenile cod capture between habitat types $\left(\log _{10}\right.$ trans formed). Means are reported with $95 \%$ confidence interval

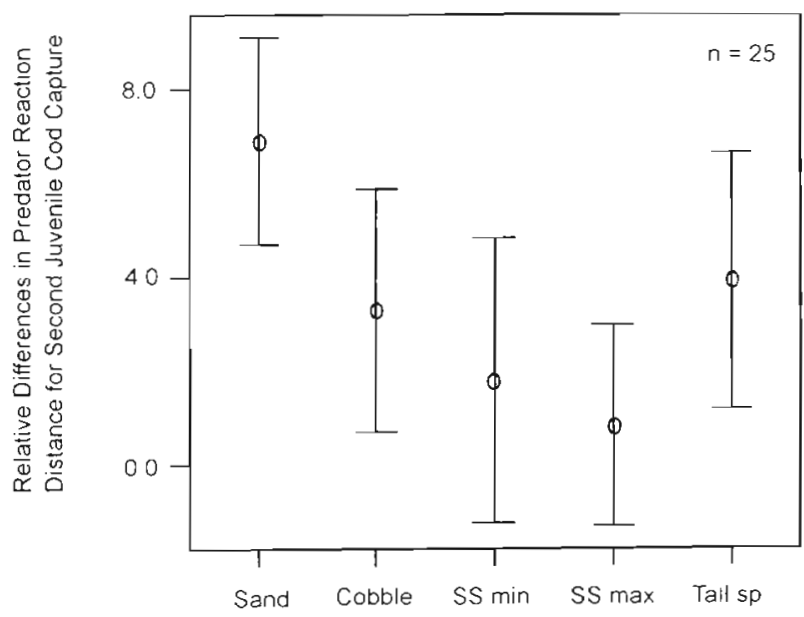

Fig. 6. Comparison of relative differences in predator reaction distance for second juvenile cod capture between habitat types (square root transformed). Means are reported with $95 \%$ confidence interval

As for first capture, the latent period to second capture (Fig. 5) was not significantly different between habitat types (ANOVA, $F=0.54, p<0.709$ ). Once again, there were significant differences between habitat types for predator reaction distance for second capture (Fig. 6; 2-way ANOVA, $F=5.96, p<0.004$ ). The Bonferroni/Dunn test (Table 2) indicated a highly significant difference between sand habitat and each of the other 4 habitat types. SS max also proved to be significantly different than Tall sp. Further, predator reaction distance for first capture was found to be significantly shorter than predator reaction distance for first capture ( 2 -sample $t$-test, $t=2.54, \mathrm{p}<0.0072$ ). 


\section{DISCUSSION}

The results of these experiments clearly indicate that increases in habitat complexity led to decreased predator success and increased 0 -yr cod survivorship in an experimental setting. 0-yr survivorship was lowest for experimental habitats that emulated chronic fishing impacts to the bottom, and highest for the habitat with the highest density of structures, representing areas unimpacted by fishing activity. In this study, the presence of structure in bottom habitat le.g. cobble and cobble with sponge mimics) resulted in a significant decrease in total predator-induced mortality for 0 -yr cod in comparison with that which was observed over flat sand. Over flat sand habitat, 0 -yr cod sought refuge from a foraging conspecific by escaping to the air-water interface at the opposite end of the experimental arena, suggesting cod would use a long-distance flight response to avoid predation. However, this strategy was not successful, with an average 0 -yr mortality of $93.4 \%$ over sand.

The cobble treatment showed a statistically significant reduction in 0 -yr mortality at $66.8 \%$. Here the crevices or interstices between the base of cobbles and the sand provided cover for 0 -yr cod. Further reduction in 0 -yr mortality occurred in the treatments using emergent sponge mimics, with $46.6 \%$ mean mortality for SS min, $32.2 \%$ for SS max, and $60.2 \%$ for Tall sp. For treatments which featured sponge mimics attached to cobbles, 0 -yr cod were observed to seek shelter both within the sponges and at the base of cobbles. These results are consistent with recent laboratory studies that found the highest juvenile cod survivorship over cobble-gravel habitat (interstices) and vertical relief in the form of high densities of eelgrass (Gotceitas \& Brown 1993, Gotceitas et al. 1995, 1997, Fraser et al. 1996). Our findings are also consistent with field observations in the nearshore region of Nova Scotia (Tupper \& Boutilier 1995a,b) and observational studies using submersibles on the northeast peak of Georges Bank (Lough et al. 1989). These studies found the highest survivorship for juvenile cod and haddock to occur over rock reefs and surmised a similar pattern of survivorship on gravel pavement, with the highest mortality occurring over sand.

In this study, high density of emergent epifauna was shown to provide a greater reduction in 0-yr mortality (SS max mean $32.2 \% 0$-yr consumed) than epifauna height (Tall sp mean $60.2 \%$ ). The Tall sp habitat provided $7 \mathrm{~cm}$ of additional vertical cover from predation relative to SS min and SS max, but may also have served to restrict the escape behavior of prey. Average mortality over SS min (46.6\%) was also lower than Tall $\mathrm{sp}$, although both habitat types featured similar densities of sponge mimics. Over both SS min and SS max,
0 -yr cod were observed to seek refuge at the base of the cobble with sponge mimic, often remaining stationary for the duration of the trial. Over Tall sp habitat, 0 -yr cod were observed to actively swim or keep station several centimeters below the top of the habitat. Here they made use of the habitat, but also remained more accessible to the foraging predator. Further experiments are required to elucidate these patterns.

Enhanced habitat structure was predicted to increase latent period for both first and second capture as compared to bare sand habitat, as 0 -yr juveniles made use of available cover. Results of analysis of latency to first and second 0 -yr capture did not confirm our predictions. This points to the highly contingent and unpredictable nature of any one predator-prey interaction. However, predator reaction distance for both first and second captures were observed to differ between habitat types, with significant differences noted between sand habitat and both short sponge habitats for first capture and between sand habitat and all 4 more highly structured habitats for second capture. Furthermore, predator reaction distance was significantly greater for first capture than for second. This suggests that prey vigilance may have increased as the predators spent more time stalking them.

Tupper \& Boutilier (1995a) observed juvenile cod in the nearshore environment exhibiting site fidelity following settlement. In the present study, prey position relative to bottom habitat varied widely prior to first capture. However, following the first capture, the prey sought refuge in available structure, often remaining fixed to a particular site for the duration of the trial. This led to a corresponding reduction in the distance from which a predator was able to visually perceive a prey item. For example, there was a $79 \%$ reduction in mean predator reaction distance over SS max from first to second capture (Table 3 ).

The nature and extent of habitat alteration by mobile fishing gear will likely vary with fishing intensity (Auster 1998, Auster \& Langton 1998). Results indicate that 0 -yr cod association with the complexity provided by cobble and sponge mimics inhibited pursuit of prey by predators, and increased 0 -yr survivorship over 0 -yr cod in habitats lacking such structure, supporting a connection between seafloor habitat complexity and the survivorship of 0 -yr Atlantic cod and implying that fishing activity that reduces habitat complexity will compromise future year classes in the fishery. The role of seafloor habitat in the survivorship of 0 -yr cod was investigated in the context of indirect impacts by mobile fishing gear on recruitment to harvested fish populations. Reductions in epifaunal height and density were simulated to specify a range of potential impacts of fishing activity to the seafloor. Mobile fish- 
Table 3. Comparison of total mortality, latent period for first and second 0 -yr cod capture, and predator reaction distance for first and second juvenile cod capture, by habitat type. Mean and standard deviation are reported for each metric

\begin{tabular}{|c|c|c|c|c|c|c|c|c|c|c|}
\hline \multirow[t]{2}{*}{ Habitat } & \multicolumn{2}{|c|}{$\begin{array}{c}\text { Total mortality } \\
(\% 0-y r \\
\text { consumed })\end{array}$} & \multicolumn{2}{|c|}{$\begin{array}{l}\text { Latent period } \\
\text { to first } \\
\text { capture(min) }\end{array}$} & \multicolumn{2}{|c|}{$\begin{array}{l}\text { Predator } \\
\text { reaction distance } \\
\text { first capture }(\mathrm{cm})\end{array}$} & \multicolumn{2}{|c|}{$\begin{array}{l}\text { Latent period } \\
\text { to second } \\
\text { capture (min) }\end{array}$} & \multicolumn{2}{|c|}{$\begin{array}{c}\text { Predator reaction } \\
\text { distance second } \\
\text { capture }(\mathrm{cm})\end{array}$} \\
\hline & Mean & SD & Mean & $\mathrm{SD}$ & Mean & SD & Mean & $\mathrm{SD}$ & Mean & $\mathrm{SD}$ \\
\hline Sand & 93.40 & 14.76 & 5.40 & 4.56 & 60.00 & 15.81 & 13.20 & 12.68 & 50.00 & 23.70 \\
\hline Cobble & 66.8 & 23.70 & 21.60 & 30.50 & 43.00 & 24.90 & 27.00 & 55.80 & 14.00 & 11.40 \\
\hline $\mathrm{SS} \min$ & 46.60 & 18.62 & 23.40 & 25.21 & 23.00 & 15.65 & 17.00 & 22.80 & 8.00 & 11.51 \\
\hline$S S \max$ & 32.20 & 23.70 & 3.80 & 2.95 & 14.00 & 14.94 & 4.20 & 7.16 & 3.00 & 6.71 \\
\hline Tall sp & 60.20 & 15.21 & 27.60 & 55.62 & 40.00 & 34.50 & 11.60 & 12.28 & 19.00 & 11.40 \\
\hline
\end{tabular}

ing gear has been shown to directly alter the physical structure of the seafloor, reducing complexity of the substratum, including any associated epibionts (Auster et al. 1996). Collie et al. (1997) found higher numbers of benthic organisms, biomass, species richness and species diversity in undredged sites relative to dredged sites on the northeast peak of Georges Bank. Auster et al. (1996) showed that emergent epibenthic organisms on several banks of the Gulf of Maine are easily removed by mobile fishing gear. We believe the comparison of all 5 treatments provides a spectrum of potential impacts to the seafloor from fishing activity. No amount of fishing activity will convert cobble to sand, however. Auster et al. (1998) observed instances in which pebble-cobble bottom is covered by a layer of sand while continuing to support emergent epifauna. In this case, were the epifauna attached to the underlying pebble-cobble removed by fishing activity, the resultant surface would be similar in its lack of structure to our sand treatment, which provides little to no cover from predation.

Uitimately, our objective is to predict the impact of habitat alteration on associated fish populations. We recognize the limitations of laboratory experimentation for studies of wide-ranging predators. Limited space in aquaria constrains movement significantly as well as prey responses (e.g. long-distance flight as a predator avoidance strategy) that might otherwise range over much wider areas. This is an inherent limitation in all laboratory experiments of this kind. Clark \& Green (1990) observed movement rates of $3 \mathrm{~km} \mathrm{~d}^{-1}$ for adult cod in the nearshore environment of Nova Scotia, using sonic telemetry. The experimental aquarium captures approximately $0.03 \%$ of the potential range of the predators used in these experiments. To capture even $1 \%$ of a cod's daily range of movement, an experimental aquarium would have to be $30 \mathrm{~m}^{2}$, significantly and prohibitively larger than the aquarium used here. However, limitations on the size of experimental aquaria need not preclude the generation of data regarding rela- tive differences in species interactions under particular sets of conditions.

Rather than estimate absolute values for natural mortality, we quantified relative differences in habitatspecific 0 -yr mortality. These data will, in addition to empirical data collected in the field, be used to parameterize a dynamic model of 0 -yr cod survivorship The model will simulate 0 -yr survivorship as a function of seafloor habitat complexity and the size, number, and configuration of marine protected areas designed to protect such habitat (see Lingholm et al. 1998) Through modeling we can use the results of the smallscale laboratory experiments described here, in conjunction with future empirical data collected in the field (e.g. Auster et al. 1998), to predict fish populationlevel responses to changes in seafloor habitat complexity.

Acknowledgements. We would like to thank Allison Aquilana and Liana Hammersley for help in preliminary lab experiments and Arthur Lima for vital support in setting-up and maintaining the aquaria. We would also like to thank $\mathrm{Dr}$ Linda Kling of the University of Maine at Orono and Dr Rich Langton of the Maine Department of Marine Resources, for making 0 -yr cod available to us. The 0 -yr cod were produced by Dr Larry Buckley at the Narragansett Laboratory of the National Marine Fisheries Service and were cultured at the Aquaculture Center at the University of Maine at Orono by Dr Kling. Predators were captured on the 'Miss Francine' and the 'Frances Gail', both out of Galilee, Rhode Island. Funding for experimental aquaria was provided by grants from the Max and Virtoria Dreyfus Foundation and Connecticut Sea Grant to P.J.A. J.L. was supported by grants from the Kendall Fourdation of Boston, Massachusetts, and the Pew Charitable Trusts. P.J.A was supported by the National Undersea Research Center and Stellwagen Bank National Marine Sanctuary. The views expressed herein are those of the authors and do not necessarily reflect the views of NOAA or any of its sub-agencies

\section{LITERATURE CITED}

Anderson JT (1988) A review of size dependent survival during pre-recruit stages of fishes in relation to recruitment. J Northwest A.tl Fish Sci 8:55-66 
Auster PJ (1988) A review of the present understanding of marine fish communities. J Northwest Atl Fish Sci 8:67-75

Auster PJ (1998) A conceptual model of the impacts of fishing gear on the integrity of fish habitats. Conserv Biol 12:1-6

Auster PJ, Langton RW (1998) The effects of fishing on fish habitat. In: Benaka L (ed) Fish habitat: essential fish habitat $(E F H)$ and rehabilitation. American Fisheries Society, Bethesda, MD, p 150-187

Auster PJ, Malatesta RJ (1991) Effects of scale on predation patterns. In: Shumway SE, Sandifer PE (eds) An international compendium of scallop biology and culture. World Aquaculture Society, Baton Rouge, LA, p 198-203

Auster PJ, Malatesta RJ, LaRosa SC, Cooper RA, Stewart LL. (1991) Microhabitat utilization by the megafaunal assemblage at a low relief outer continental shelf site-Middle Atlantic Bight, USA. J Northwest Atl Fish Sci 11:59-69

Auster PJ, Malatesta RJ, LaRosa SC (1995) Patterns of microhabitat utilization by mobile megafauna on the southern New England (USA) continental shelf and slope. Mar Ecol Prog Ser 127:77-85

Auster PJ, Malatesta RJ, Langton RW, Watling L, Valentine PC, Donaldson CLS, Langton EW, Shepard AN, Babb IG (1996) The impacts of mobile fishing gear on seafloor habitats in the Gulf of Maine (Northwest Atlantic): implications for conservation of fish populations. Rev Fish Sci 4: 185-202

Auster PJ, Michalopoulos C, Valentine PC, Malatesta RJ (1998) Delineating and monitoring habitat management units in a temperate deep-water marine protected area. In: Munro NWP, Willison JAM (eds) Linking protected areas with working landscapes, conserving biodiversity. Science and Management of Protected Areas Association, Wolfville, Nova Scotia, p 169-185

Bond CE (1996) Biology of fishes. Saunders College Publishing, Fort Worth, TX

Carr MH (1991) Habitat selection and recruitment of an assemblage of temperate zone reef fishes. J Exp Mar Biol Ecol 146:113-137

Clark DS, Green JM (1990) Activity and movement patterns of juvenile Atltantic cod, Gadus morhua, in Conception Bay, Newfoundland, as determined by sonic telemetry. Can J Zool 68:1434-1442

Collie JS, Escanero GA, Valentine PC (1997) Elfects of bottom fishing on the benthic megafauna of Georges Bank. Mar Ecol Prog Ser 155:159-172

Connell SD, Jones GP (1991) The influence of habitat complexity on postrecruitment processes in a temperate reef population. J Exp Mar Biol Ecol 151:271-294

Fraser S, Gotceitas V, Brown JA (1996) Interactions between age-classes of Atlantic cod and their distribution between bottom substrates. Can J Fish Aquat Sci 53:305-314

Freese L, Auster PJ, Heifetz J, Wing B (1999) Impacts of trawling on seafloor habitat in the Gulf of Alaska: changes in habitat structure and associated invertebrate taxa. Mar Ecol Prog Ser (in press)

Gotceitas V, Brown JA (1993) Substrate selection by juvenile Atlantic cod (Gadus morhua): effects of predation risk. Oecologia 93:31-37

Gotceitas V, Fraser S, Brown JA (1995) Habitat use by juvenile Atlantic cod (Gadus morhua) in the presence of an actively foraging and non-foraging predator. Mar Biol 123: $421-430$

Editorial responsibility: Kenneth Sherman (Contributing Editor), Narragansett, Rhode Island, USA
Gotceitas V, Fraser S, Brown JA (1997) Use of eelgrass beds (Zostera marina) by juvenile Atlantic cod (Gadus morhua). Can J Fish Aquat Sci 54:1306-1319

Gregory RS, Anderson JT, Dalley EL (1997) Distribution of juvenile Atlantic cod (Gadus morhua) relative to available habitat in Placentia Bay, Newfoundland. NAFO Sci Counc Stud 29:3-12

Heck KL, Crowder LB (1991) Habitat structure and predatorprey interactions in vegetated aquatic systems. In: Bell SS, McCoy ED, Mushinsky HR (eds) Habitat structure: the physical arrangement of objects in space. Chapman and Hall, London

Kaiser MJ, Spencer BE (1994) Fish scavenging behaviour in recently trawled areas. Mar Ecol Prog Ser 112:41-49

Kleinbaum DG, Kupper LL, Muller KE (1988) Applied regression analysis and other multivariable methods. Duxbury Press, Belmont, CA

Langton RW (1994) Fishing effects on demersal fish habitats. In: Langton RW, Pearce JB, Gibson JA (eds) Selected living resources, habitat conditions, and human perturbations of the Gulf of Maine: environmental and ecological considerations for fishery management. NOAA TechMemo NMFS-NE-106, Woods Hole, MA

Langton RW, Auster PJ, Schneider DC (1995) A spatial and temporal perspective of research and management of groundfish in the northwest Atlantic. Rev Fish Sci 3: 201-229

Lindholm J, Ruth M, Kaufman L, Auster PJ (1998) The marine refuge as a fishery management tool: a modeling approach to the design of marine refugia. In: Munro NWP, Willison JAM (eds) Linking protected areas with working landscapes, conserving biodiversity. Science and Management of Protected Areas Association, Wolfville, Nova Scotia, p 138-168

Lough RG, Valentine PC, Potter DC, Auditore PJ, Bolz GR, Neilson JD, Perry RI (1989) Ecology and distribution of juvenile cod and haddock in relation to sediment type and bottom currents on eastern Georges Bank. Mar Ecol Prog Ser 56:1-12

Minitab (1994) Minitab reference manual. Minitab Inc, State College, PA

Sale P (1991) The ecology of fishes on coral reefs. Academic Press, San Diego, CA

Schwinghamer P, Guigne JY, Siu WC (1996) Quantifying the impact of trawling on benthic habitat structure using high resolution acoustics and chaos theory. Can J Fish Aquat Sci 53:288-296

Scott WB, Scott MG (1988) Atlantic fishes of Canada. University of Toronto Press, Toronto

Sissenwine MP (1984) Why do fish populations vary? In: May RM (ed) Exploitation of marine communities. SpringerVerlag, New York, p 59-94

Sogard SM (1997) Size-selective mortality in the juvenile stage of teleost fishes: a review. Bull Mar Sci 60: $1129-1157$

Sokal RR, Rohlf FJ (1995) Biometry. WH Freeman, New York

Tupper M. Boutilier RG (1995a) Effects of habitat on settlement, growth, and post-settlement survival of Atlantic cod (Gadus morhua). Can J Fish Aquat Sci 52:1834-1841

Tupper M, Boutilier RG (1995b) Size and priority at settlement determine growth and competitive success of newly settled Atlantic cod. Mar Ecol Prog Ser 118:295-300

Submitted: September 23, 1998; Accepted: December 30, 1998 Proofs received from author(s): April 12, 1999 